\title{
Article \\ Characteristics and Drivers of Soil Organic Carbon Saturation Deficit in Karst Forests of China
}

\author{
Limin Zhang ${ }^{1,2}{ }^{\mathbb{D}}$, Yang Wang ${ }^{1}$, Jin Chen ${ }^{1}$, Ling Feng ${ }^{1}$, Fangbing Li $^{1}$ and Lifei Yu ${ }^{1, *(\mathbb{D})}$ \\ 1 College of Life Sciences, Guizhou University, Guiyang 550025, China; zhanglimin563406@163.com (L.Z.); \\ wangyang20218910@126.com (Y.W.); gs.chenjin20@gzu.edu.cn (J.C.); 15870149772@163.com (L.F.); \\ lifangbing9685@163.com (F.L.) \\ 2 Institute of Guizhou Mountain Resources, Guizhou Academy of Sciences, Guiyang 550001, China \\ * Correspondence: lfyu@gzu.edu.cn
}

check for updates

Citation: Zhang, L.; Wang, Y.; Chen, J.; Feng, L.; Li, F.; Yu, L. Characteristics and Drivers of Soil Organic Carbon Saturation Deficit in Karst Forests of China. Diversity 2022, 14, 62. https://doi.org/10.3390/ d14020062

Academic Editors: Michael Wink, Mladen Kučinić and Vlatka Mičetić Stanković

Received: 23 December 2021

Accepted: 14 January 2022

Published: 18 January 2022

Publisher's Note: MDPI stays neutral with regard to jurisdictional claims in published maps and institutional affiliations.

Copyright: (c) 2022 by the authors. Licensee MDPI, Basel, Switzerland. This article is an open access article distributed under the terms and conditions of the Creative Commons Attribution (CC BY) license (https:// creativecommons.org/licenses/by/ $4.0 /)$.

\begin{abstract}
Karst forests have complex and unique carbon cycle characteristics. Soil organic carbon saturation deficit (CSD) is an important indicator of soil organic carbon (SOC) sequestration potential; exploring its characteristics and driving factors is a priority theme in current research on the carbon cycles of terrestrial ecosystems. In this study, 171 topsoil samples from typical karst forests in southwest China were used as the study objects. A SOC maximum saturation capacity model was constructed using the boundary line method. The CSD is equal to the maximum saturated capacity of SOC minus the current SOC. We analyzed the CSD and its main driving factors in different regions and succession stages. The results showed that the fractions of carbon and SOC contents in the karst forests at different successional stages in descending order were as follows: climax stage $>$ arbor stage $>$ shrub stage $>$ herb stage. The CSD was the highest at the herb stage in Maolan, Yuntai Mountain, and Dashahe at $83.04 \%, 89.99 \%$, and $89.97 \%$, respectively, followed by the shrub stage with $48.69 \%$, $78.50 \%$, and $84.95 \%$, and the lowest at the arbor stage with $25.69 \%, 43.44 \%$, and $60.49 \%$. The main drivers of CSD in the karst forest of Maolan were litter carbon input, total nitrogen, total phosphorus, and total SOC, and were litter carbon input at Yuntai Mountain and litter carbon input and neutral phosphatase at Dashahe. The results indicate that the core driver of CSD in the karst forest is litter carbon input, and this can be adjusted in the future to regulate the carbon sequestration capacity of SOC.
\end{abstract}

Keywords: karst forests; soil organic carbon; driving factors; carbon sequestration potential

\section{Introduction}

Soils are considered the largest terrestrial pool of global carbon. Soil organic carbon (SOC) pool is an important and variable carbon reservoir in terrestrial ecosystems and a potential sink of greenhouse gases that can exhibit significant spatial variation [1,2]. The forest SOC pool is an important component of the forest ecosystem; $73 \%$ of global soil carbon is stored in forest soils. Therefore, it plays an irreplaceable role in maintaining the global climate system, regulating the global carbon balance, and slowing the rise of atmospheric greenhouse gas concentrations [3,4]. Small changes in this carbon pool, especially in the mineral particle organic carbon $(<53 \mu \mathrm{m})$, will affect the global carbon balance and lead to global climate change [5].

Numerous studies have found that SOC eventually reaches equilibrium as exogenous carbon inputs continue to increase [6-8], i.e., soil carbon saturation [9]. Stewart et al. [10] and Feng et al. [11] estimated the maximum saturation of SOC in grassland, agricultural land, and forest by constructing a model of the maximum saturation capacity of SOC, thereby providing a foundation for subsequent studies on the carbon sequestration potential of SOC and the relevant influencing factors. In recent years, research on SOC in forest ecosystems has focused on the sequestration of SOC, decomposition of litter, and the influence of environmental factors on SOC at large spatial scales [12,13]. Zhou et al. [14] 
found that soil carbon content in China's forest ecosystems accounted for 3/4 of the total forest ecosystem; Huang et al. [15] found that SOC content increased with the gradual recovery of vegetation, and soil carbon sequestration capacity was enhanced through the study of different vegetation restoration processes in Maolan. Zhang et al. [16] and Lal et al. [17] found that changes in soil carbon flux were mainly influenced by the interaction of vegetation, climate, and soil properties. Soil organic carbon saturation deficit (CSD) is equal to the maximum saturated capacity of SOC minus the current SOC [10], which is an important index directly reflecting soil carbon sequestration potential. Di et al. [18] found that in agricultural soils, increased application of organic fertilizers significantly reduced CSD over time, resulting in less space for future carbon sequestration, and carbon input was the main influence factor on CSD. At present, there have been few studies on the characteristics and drivers of saturation deficit in forest soils.

Karst forests are forest ecosystems that are distributed on landscapes with limestone, dolomite, and carbonate as the main bedrock. Plants in karst forests are constrained by soil topography [19,20]; as a unique ecosystem, the topography, hydrothermal conditions, and soil development conditions differ from those of non-karst areas [21-24]. Based on this complexity and specificity, the study of CSD in karst forest ecosystems is highly relevant. The key questions addressed in this study were: (1) What are the levels of CSD at different successional stages in karst forests, and how does this affect the future carbon sequestration potential? (2) What are the main drivers of CSD in karst forests, and how can they be regulated?

\section{Materials and Methods}

\subsection{Overview of the Study Areas}

The study areas were located in Maolan National Nature Reserve, Shibing Yuntai Mountain Nature Reserve, Daozhen Dashahe Nature Reserve, Nayong Gongtong Nature Reserve, Pogang Karst Vegetation Nature Reserve, Kuankuoshui Nature Reserve, Puding Huoyan Mountain Nature Reserve, Jiangkou Huanggu Mountain Nature Reserve, Kaiyang Zijiang Geosuture, and Wangmo Bijia Mountain, all in Guizhou Province, China (Figure 1). These study areas are typical karst forests that present climax communities because they are long-established forests that experience low levels of disturbance, and thus they can be used to model the maximum saturation capacity of SOC in karst forests. Among these karst forests, three areas with rich successional stages were selected from south to north, namely, Maolan National Nature Reserve, Shibing Yuntai Mountain Nature Reserve, and Daozhen Dashahe Nature Reserve, to explore CSD and the driving factors at different successional stages. The Maolan National Nature Reserve has a total area of $213 \mathrm{~km}^{2}$ with a maximum elevation of $1079 \mathrm{~m}$, a minimum elevation of $430 \mathrm{~m}$, and an average elevation of $700 \mathrm{~m}$. It has a central subtropical southern monsoon climate with an average annual temperature of $18.3^{\circ} \mathrm{C}$, annual precipitation of $1321 \mathrm{~mm}$, and an annual sunshine duration of $1271 \mathrm{~h}$. Most parts of the reserve are central subtropical primary karst forests, with mixed evergreen, deciduous broad-leaved tree species. There are different degrees of successional communities, with 1203 species of vascular plants in 154 families and 514 genera [15]. The Yuntai Mountain Nature Reserve has a total area of $47 \mathrm{~km}^{2}$ with a maximum elevation of $1869 \mathrm{~m}$, a minimum elevation of $486 \mathrm{~m}$, and an average elevation of $526 \mathrm{~m}$. It has a humid subtropical monsoon climate with an average annual temperature of $16.4^{\circ} \mathrm{C}$, annual precipitation of $1130 \mathrm{~mm}$, and an annual sunshine duration of $1197 \mathrm{~h}$. The reserve has the typical karst topography of southern China; the area is also a World Heritage Site with vegetation growing on dolomite rocks and a native and relatively stable karst forest [25]. The Dashahe Nature Reserve has a total area of $270 \mathrm{~km}^{2}$ with a maximum elevation of $1940 \mathrm{~m}$, a minimum elevation of $564 \mathrm{~m}$, and an average elevation of $1252 \mathrm{~m}$. It has a humid monsoon climate with an average annual temperature of $12.1^{\circ} \mathrm{C}$, annual precipitation of $1194 \mathrm{~mm}$, and an annual sunshine duration of $1134 \mathrm{~h}$. The reserve is located in a karst landscape on soluble carbonate rock formations and is extremely rich in biological resources. There are 3594 species of plants in 1082 genera of 296 families and 208 species in 95 genera 
of 47 families of macrofungi, making it one of the most valuable gene pools of biological species in the central subtropics of China [26].

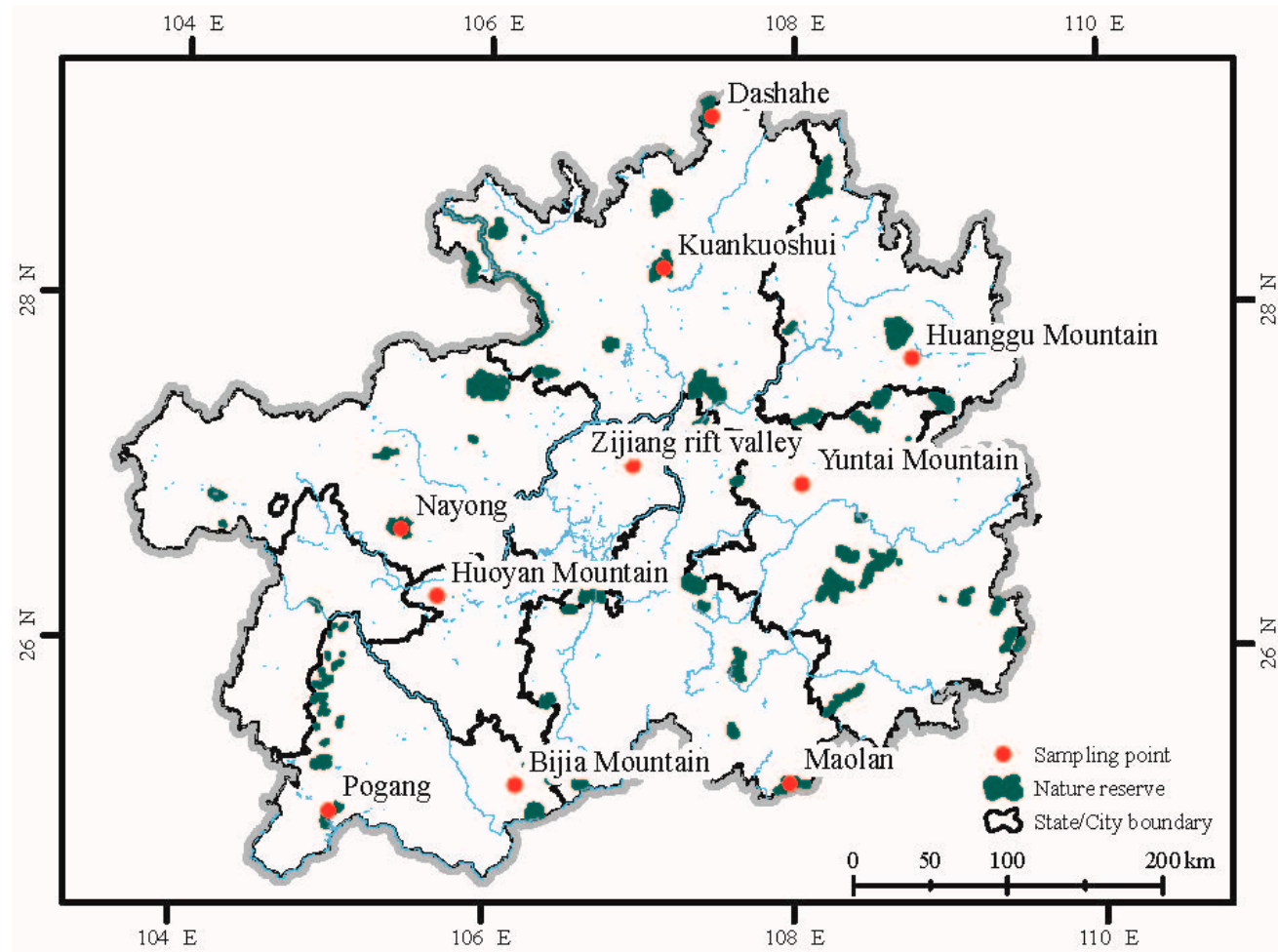

Figure 1. Distribution map of sample points.

\subsection{Research Methodology}

\subsubsection{Sample Site Selection and Vegetation Survey}

A total of 57 sample plots were established within seven typical karst forest climax communities, and three study areas in each of four different successional stages were selected from south to north, with three sample plots in each community. The sample plots were $2 \mathrm{~m} \times 5 \mathrm{~m}$ for the herb stage, $4 \mathrm{~m} \times 10 \mathrm{~m}$ for the shrub stage, $20 \mathrm{~m} \times 20 \mathrm{~m}$ for the arbor stage, and $20 \mathrm{~m} \times 20 \mathrm{~m}$ for the climax stage. Ten small sample squares were chosen in each sample plot for vegetation surveys. The surveys followed conventional community survey methods [27], where tree plant species, the number of plants, shrub and herb species, and habitat factors including elevation, height, slope degree, slope direction, and soil type were recorded in the sample plots. The information is shown in Tables 1 and 2. 
Table 1. The basic information of the environmental background of different sample point.

\begin{tabular}{|c|c|c|c|c|c|c|c|c|c|c|}
\hline Area & $\begin{array}{c}\text { Succession } \\
\text { Stage }\end{array}$ & Coordinates & $\begin{array}{l}\text { Elevation } \\
\text { (m) }\end{array}$ & $\begin{array}{l}\text { Precipitation } \\
(\mathrm{mm})\end{array}$ & $\begin{array}{c}\text { Annual Mean } \\
\text { Temperature } \\
\left({ }^{\circ} \mathrm{C}\right)\end{array}$ & Aspect & Dominant Species & Soil Bedrock & Soil Type & $\begin{array}{c}\text { Sample Size } \\
\left(\mathrm{m}^{2}\right)\end{array}$ \\
\hline \multirow{4}{*}{ Maolan } & $\begin{array}{l}\text { Herb } \\
\text { stage }\end{array}$ & 108.0325 .26 & 840 & 1590.70 & 19.75 & NW & $\begin{array}{c}\text { Pteridium revolutum, Imperata } \\
\text { cylindrical var. major, } \\
\text { Pogonatherum crinitum, } \\
\text { Trisetum bifidum }\end{array}$ & $\begin{array}{l}\text { Dolomite } \\
\text { limestone }\end{array}$ & $\begin{array}{l}\text { Clay, black } \\
\text { limestone soil }\end{array}$ & $2 \times 5$ \\
\hline & $\begin{array}{l}\text { Shrub } \\
\text { stage }\end{array}$ & 107.9425 .30 & 820 & 1590.70 & 19.75 & SW & $\begin{array}{l}\text { Pyracantha fortuneana, Nandina } \\
\text { domestica, Lindera communis, } \\
\text { Myrsine semiserrata, Clausena } \\
\text { dunniana, Ulmus parvifolia }\end{array}$ & $\begin{array}{l}\text { Dolomite } \\
\text { limestone }\end{array}$ & $\begin{array}{l}\text { Clay, black } \\
\text { limestone soil }\end{array}$ & $4 \times 10$ \\
\hline & $\begin{array}{l}\text { Arbor } \\
\text { stage }\end{array}$ & 107.9525 .29 & 840 & 1590.70 & 19.75 & SW & $\begin{array}{c}\text { Swida wilsoniana, Machilus } \\
\text { chienkweiensis, Lindera } \\
\text { communis, Cladrastis platycarpa, } \\
\text { Choerospondias axillaris }\end{array}$ & $\begin{array}{l}\text { Dolomite } \\
\text { limestone }\end{array}$ & $\begin{array}{l}\text { Clay, black } \\
\text { limestone soil }\end{array}$ & $20 \times 20$ \\
\hline & $\begin{array}{l}\text { Climax } \\
\text { stage }\end{array}$ & 107.9925 .19 & 850 & 1590.70 & 19.75 & SW & $\begin{array}{c}\text { Swida wilsoniana, Pittosporum } \\
\text { brevicalyx, Cyclobalanopsis } \\
\text { multiervis, Acerwangchii, } \\
\text { Carpinus pubescens, } \\
\text { Phoebe crassipedicella }\end{array}$ & $\begin{array}{l}\text { Dolomite } \\
\text { limestone }\end{array}$ & $\begin{array}{l}\text { Clay, black } \\
\text { limestone soil }\end{array}$ & $20 \times 20$ \\
\hline \multirow{4}{*}{$\begin{array}{l}\text { Yuntai } \\
\text { Mountain }\end{array}$} & $\begin{array}{l}\text { Herb } \\
\text { stage }\end{array}$ & 108.1227 .18 & 873 & 1083.80 & 17.29 & SW & $\begin{array}{c}\text { Awn, Ophiopogon japonicus, } \\
\text { Ficus tikoua Bur., } \\
\text { Athyrium dissitifolium }\end{array}$ & Carbonate rock & $\begin{array}{l}\text { Clay, black } \\
\text { limestone soil }\end{array}$ & $2 \times 5$ \\
\hline & $\begin{array}{l}\text { Shrub } \\
\text { stage }\end{array}$ & 108.1627 .13 & 865 & 1083.80 & 17.29 & NW & $\begin{array}{c}\text { Bridelia tomentosa, Neillia } \\
\text { sinensis Oliv., Viburnum } \\
\text { dilatatum Thunb., Nothopanax } \\
\text { davidii Franch.Harms }\end{array}$ & Carbonate rock & $\begin{array}{l}\text { Loam, black } \\
\text { limestone soil }\end{array}$ & $4 \times 10$ \\
\hline & $\begin{array}{l}\text { Arbor } \\
\text { stage }\end{array}$ & 108.1027 .10 & 841 & 1083.80 & 17.29 & SW & $\begin{array}{c}\text { Lindera communis Hemsl., } \\
\text { Pistacia chinensis Bunge, } \\
\text { Quercus acutissima Carr., } \\
\text { Platycarya strobilacea }\end{array}$ & Carbonate rock & $\begin{array}{l}\text { Loam, black } \\
\text { limestone soil }\end{array}$ & $20 \times 20$ \\
\hline & $\begin{array}{l}\text { Climax } \\
\text { stage }\end{array}$ & 108.1127 .12 & 875 & 1083.80 & 17.29 & NW & $\begin{array}{l}\text { Cupressus funebris, Quercus } \\
\text { dolicholepis, Platycarya } \\
\text { strobilacea, Carpinus pubescens, } \\
\text { Quercus phillyraeoides }\end{array}$ & Carbonate rock & $\begin{array}{l}\text { Loam, black } \\
\text { limestone soil }\end{array}$ & $20 \times 20$ \\
\hline
\end{tabular}


Table 1. Cont.

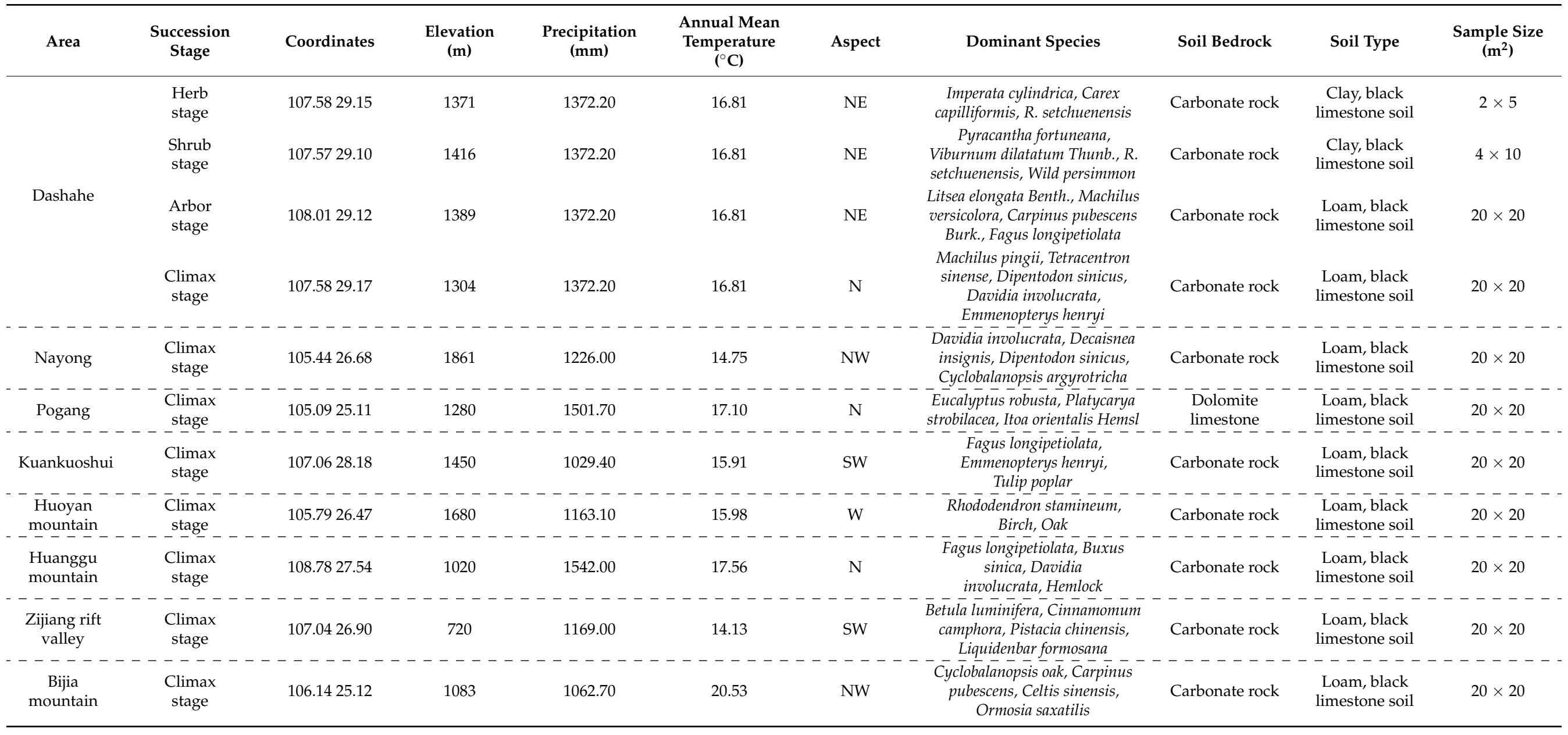


Table 2. The basic information of soil physical and chemical properties in different succession stages.

\begin{tabular}{|c|c|c|c|c|c|c|c|c|c|c|c|}
\hline Area & $\begin{array}{l}\text { Succession } \\
\text { Stage }\end{array}$ & $\mathrm{pH}$ & $\begin{array}{c}\text { BD } \\
\left(\mathrm{g} \mathrm{cm}^{-3}\right)\end{array}$ & $\underset{\left(\mathrm{g} \mathrm{kg}^{-1}\right)}{\mathrm{SOC}}$ & $\begin{array}{c}\mathrm{TN} \\
\left(\mathrm{g} \mathrm{kg}^{-1}\right)\end{array}$ & $\begin{array}{c}\mathrm{TP} \\
\left(\mathrm{g} \mathrm{kg}^{-1}\right)\end{array}$ & $\begin{array}{c}\text { Lci } \\
\left(\mathrm{g} \mathrm{C} \mathrm{m}^{-2}\right)\end{array}$ & $\begin{array}{c}\mathrm{Ca} \\
\left(\mathrm{g} \mathrm{kg}^{-1}\right)\end{array}$ & $\begin{array}{c}\mathrm{Ur} \\
\left(\mathrm{mg} \mathrm{g}^{-1} 24 \mathrm{~h}^{-1}\right)\end{array}$ & $\begin{array}{c}\text { Npa } \\
\left(\mathrm{mg} \mathrm{g}^{-1} 24 \mathrm{~h}^{-1}\right)\end{array}$ & $\begin{array}{c}\mathrm{Sa} \\
\left(\mathrm{mg} \mathrm{g}^{-1} 24 \mathrm{~h}^{-1}\right)\end{array}$ \\
\hline \multirow{5}{*}{ Maolan } & Herb stage & $7.34 \pm 0.08 \mathrm{a}$ & $1.31 \pm 0.02 \mathrm{a}$ & $28.34 \pm 2.80 \mathrm{~d}$ & $1.57 \pm 0.03 \mathrm{~d}$ & $0.36 \pm 0.01 \mathrm{~d}$ & $12.27 \pm 1.08 \mathrm{~d}$ & $1.38 \pm 0.05 c$ & $0.09 \pm 0.01 \mathrm{c}$ & $0.65 \pm 0.08 b$ & $7.08 \pm 0.23 b$ \\
\hline & Shrub stage & $7.63 \pm 0.07 \mathrm{a}$ & $1.25 \pm 0.01 \mathrm{a}$ & $65.30 \pm 4.36 c$ & $6.75 \pm 0.43 c$ & $1.01 \pm 0.10 \mathrm{~b}$ & $33.57 \pm 2.44 c$ & $3.19 \pm 0.48 b$ & $0.89 \pm 0.48 b$ & $2.62 \pm 0.15 a$ & $7.36 \pm 0.14 b$ \\
\hline & Arbor stage & $7.23 \pm 0.06 a$ & $1.20 \pm 0.01 \mathrm{a}$ & $85.22 \pm 3.69 b$ & $7.55 \pm 0.11 b$ & $0.77 \pm 0.02 \mathrm{c}$ & $81.76 \pm 2.23 b$ & $4.83 \pm 0.14 \mathrm{a}$ & $1.05 \pm 0.11 b$ & $2.16 \pm 0.34 a$ & $8.22 \pm 0.22 b$ \\
\hline & Climax stage & $7.14 \pm 0.27 \mathrm{a}$ & $1.02 \pm 0.03 b$ & $94.13 \pm 3.51 \mathrm{a}$ & $8.42 \pm 1.10 \mathrm{aa}$ & $1.21 \pm 0.20 \mathrm{a}$ & $141.03 \pm 2.53 a$ & $4.83 \pm 1.02 \mathrm{a}$ & $1.62 \pm 0.45 \mathrm{a}$ & $2.79 \pm 0.33 a$ & $12.77 \pm 0.73 a$ \\
\hline & Herb stage & $8.12 \pm 0.05 a$ & $1.43 \pm 0.06 \mathrm{a}$ & $22.52 \pm 1.23 c$ & $1.88 \pm 0.08 \mathrm{~d}$ & $0.43 \pm 0.01 \mathrm{a}$ & $23.33 \pm 1.34 \mathrm{c}$ & $2.29 \pm 0.09 \mathrm{~d}$ & $0.35 \pm 0.04 \mathrm{c}$ & $0.62 \pm 0.04 \mathrm{~b}$ & $0.75 \pm 0.08 c$ \\
\hline $\begin{array}{l}\text { Yuntai } \\
\text { Moun- } \\
\text { tain }\end{array}$ & Arbor stage & $7.97 \pm 0.04 \mathrm{a}$ & $1.19 \pm 0.04 \mathrm{c}$ & $58.84 \pm 3.16 b$ & $5.43 \pm 0.25 b$ & $0.57 \pm 0.02 \mathrm{a}$ & $137.09 \pm 6.90 \mathrm{~b}$ & $6.63 \pm 0.14 a$ & $4.18 \pm 0.30 \mathrm{a}$ & $2.26 \pm 0.09 a$ & $9.86 \pm 1.99 b$ \\
\hline \multirow{5}{*}{ Dashahe } & Climax stage & $7.93 \pm 0.06 a$ & $1.17 \pm 0.02 c$ & $82.13 \pm 2.48 a$ & $6.75 \pm 0.79 \mathrm{a}$ & $0.54 \pm 0.03 a$ & $181.11 \pm 6.72 \mathrm{a}$ & $5.09 \pm 0.74 b$ & $4.25 \pm 0.76 \mathrm{a}$ & $2.08 \pm 0.24 a$ & $12.83 \pm 0.82 \mathrm{a}$ \\
\hline & Herb stage & $7.49 \pm 0.22 \mathrm{a}$ & $1.30 \pm 0.02 \mathrm{a}$ & $18.35 \pm 2.13 \mathrm{~d}$ & $1.84 \pm 0.03 \mathrm{~d}$ & $0.51 \pm 0.04 \mathrm{a}$ & $21.27 \pm 8.71 c$ & $2.26 \pm 0.38 b$ & $0.22 \pm 0.04 \mathrm{c}$ & $0.55 \pm 0.08 \mathrm{c}$ & $5.87 \pm 2.12 b$ \\
\hline & Shrub stage & $6.55 \pm 0.04 a$ & $1.18 \pm 0.03 b$ & $29.23 \pm 3.05 c$ & $2.33 \pm 0.17 c$ & $0.37 \pm 0.01 \mathrm{~b}$ & $29.25 \pm 2.34 c$ & $1.85 \pm 0.13 c$ & $0.35 \pm 0.03 c$ & $0.69 \pm 0.03 c$ & $4.67 \pm 1.51 \mathrm{~b}$ \\
\hline & Arbor stage & $6.60 \pm 0.10 \mathrm{a}$ & $1.22 \pm 0.02 b$ & $49.93 \pm 3.52 b$ & $3.77 \pm 0.29 \mathrm{~b}$ & $0.39 \pm 0.01 \mathrm{~b}$ & $98.86 \pm 7.55 b$ & $2.83 \pm 0.25 b$ & $0.74 \pm 0.10 \mathrm{~b}$ & $1.89 \pm 0.14 a$ & $10.60 \pm 1.91 \mathrm{a}$ \\
\hline & Climax stage & $7.74 \pm 0.09 \mathrm{a}$ & $1.12 \pm 0.01 \mathrm{c}$ & $78.75 \pm 2.48 a$ & $5.53 \pm 0.67 a$ & $0.69 \pm 0.03 a$ & $204.71 \pm 12.24 a$ & $3.20 \pm 0.31 \mathrm{a}$ & $2.28 \pm 0.75 a$ & $1.12 \pm 0.14 \mathrm{~b}$ & $11.11 \pm 1.74 \mathrm{a}$ \\
\hline
\end{tabular}

Note: BD is soil bulk density, SOC is soil total organic carbon, TN is total nitrogen, TP is total phosphorus, Lci is litter carbon input, Ca is exchangeable calcium, Ur is soil urease, Npa is neutral phosphatase, Sa is soil sucrase. Different lowercase letters indicate a significant difference $(p<0.05)$ among different succession stages for soil property. Contents are reported as mean \pm SE 


\subsubsection{Soil Sample Collection and Processing}

Surface soil samples were collected in each sample plot along two diagonal lines within the square plot using the "S" type five-point mixed sampling method. Three mixed samples were collected from each sample plot for a total of 171 soil samples from 57 sample plots, while 3 soil samples were collected by $100 \mathrm{~cm}^{3}$ foil sampler from each sample plot for a total of 171 and dried for the determination of soil bulk density. Sampling was carried out by removing litter from the surface and removing gravel and roots that were visible to the naked eye after sampling and mixing. One sample from eacg of the Maolan, Yuntai Mountain, and Dashahe Nature Reserves was taken back to the laboratory in a sealed plastic bag, air-dried, and finely ground through a $0.25 \mathrm{~mm}$ sieve; the other sample was taken back to the laboratory in a low-temperature sampling box and placed in an ultra-low temperature refrigerator at $-70{ }^{\circ} \mathrm{C}$ for microbiological determination. Soil samples from the seven climax communities were brought back to the laboratory in sealed plastic bags, air-dried, finely ground, and passed through a $0.25 \mathrm{~mm}$ sieve.

\subsubsection{Litter Sample Collection and Processing}

Nylon mesh was used to construct a square sampling frame with an area of $1.0 \mathrm{~m}^{2}$. We randomly selected three small subplots in each plot at the shrub, arbor, and climax stages to sample the litter. The square sampling frame was placed horizontally during sampling. The litter in the square sampling frame was collected every six months. For the herb stage, three small $1.0 \mathrm{~m}^{2}$ subplots were randomly selected in each plot, and the aboveground plant parts were harvested as the litter. A total of 36 samples were collected. All samples were brought back to the laboratory in sealed plastic bags, dried in an oven at $60{ }^{\circ} \mathrm{C}$ to a constant weight, and partly ground and passed through a $0.25 \mathrm{~mm}$ sieve to determine the carbon content of the litter.

\subsubsection{SOC Fraction}

The wet sieving method of Six et al. [28] was used to determine the SOC fraction. The procedure was as follows: $30 \mathrm{~g}$ of air-dried soil sample was passed through a $2 \mathrm{~mm}$ sieve and then placed on the top sieve of a microaggregate separator set (top $250 \mu \mathrm{m}$ sieve, bottom $53 \mu \mathrm{m}$ sieve). Then, 15 glass beads were added, and after the separator was shaken for $30 \mathrm{~min}$, the $>250 \mu \mathrm{m}$ agglomerates remained on the top sieve; the microaggregate fraction was retained on the 53-250 $\mu \mathrm{m}$ sieve, and soil particles that passed through the $53 \mu \mathrm{m}$ sieve comprised the fine particle fraction. Then, $25 \mathrm{~mL}$ of $0.25 \mathrm{~mol} / \mathrm{L} \mathrm{CaCl}_{2}$ solution was added to the bucket of the $<53 \mu \mathrm{m}$ sieve, and the mixture was centrifuged at $1730 \times g$ for $15 \mathrm{~min}$ to separate the fine particle fraction. All fractions were transferred to aluminum boxes, steamed using a water bath, and then dried in an oven at $60{ }^{\circ} \mathrm{C}$ for $12 \mathrm{~h}$. After drying, the fractions were finely ground and sieved through a $0.25 \mathrm{~mm}$ sieve and used to determine the SOC content of each fraction.

\subsubsection{Methods for Determination of Soil Sample Indicators}

Soil physical and chemical properties were determined using the methods described in Soil Agrochemical Analysis by Bao Shidan [29]. The specific methods for each soil property were as follows. Soil pH: the potentiometric method with a soil-liquid ratio of 1:2.5; soil bulk density: cutting ring weighing method; SOC: the oil bath heating potassium dichromate oxidative capacity method; soil total nitrogen: the Kjeldahl distillation method; soil total phosphorus: the molybdenum antimony anti-colorimetric method; soil total potassium: the sodium hydroxide fusion-flame photometric method; exchangeable calcium: the ammonium acetate exchange-atomic absorption spectrophotometric method. Soil enzymes were determined by the methods listed in Soil enzymes and their research methods by Song-Ying Guan [30]. Soil urease was determined by the phenol-sodium hypochlorite colorimetric method; soil sucrase was determined using the 3,5-dinitrosalicylic acid colorimetric method; soil phosphatase was determined by the sodium phosphate colorimetric method. 


\subsection{Data Processing and Analysis}

The SOC maximum saturation capacity model was constructed using the boundary line method of Feng [11] implemented by setting a boundary limit value (top 10\%), equivalent to dividing the $<53 \mu \mathrm{m}$ fine particle fraction carbon of the 10 karst forest climax communities into 9 groups and extracting the top $10 \%$ of the fine particle fraction. Using the corresponding mass proportions from each group of data, the data were used for linear regression, and the intercept was forced through the zero point to construct a model of the maximum saturation capacity of SOC in karst forests. The maximum saturation capacity of SOC in the three regions was estimated using the regression model. The CSD at each successional stage was defined as the difference between the maximum saturation capacity of SOC and the current SOC.

The data obtained were processed using Excel 2007 software, and statistical analysis was performed using SPSS 19.0 software and Duncan's new complex polar difference method. $p<0.05$ was considered as significant. Statistical analysis and driver screening were performed using $\mathrm{R}$ language software [31].

\section{Results}

\subsection{Characteristics of Changes in SOC Content}

The carbon fractions and SOC contents in different successional stages all showed significant differences (Table 3). The carbon fraction and SOC content of karst forest soil at different successional stages followed the pattern of climax stage $>$ arbor stage $>$ shrub stage $>$ herb stage, and the SOC contents of the soils in the climax stages of Maolan, Yuntai Mountain, and Dashahe were 94.13, 82.13, and $78.75 \mathrm{~g} \mathrm{C} \mathrm{kg}^{-1}$ soil, values that were $3.32,1.44$, and 1.10 times, 3.65, 1.98, and 1.40 times, and 4.29, 2.69, and 1.58 times higher than those in the herb, shrub, and arbor stages, respectively. The SOC content of each successional stage in different karst forests followed the order Maolan > Yuntai Mountain $>$ Dashahe. Among the 10 climax communities, the $<53 \mu \mathrm{m}$ carbon fraction and the SOC content were the highest in Nayong, with 23.56 and $147.11 \mathrm{~g} \mathrm{C} \mathrm{kg}^{-1}$ soil, respectively, and were lowest in Zijiang Geosuture at 8.30 and $42.05 \mathrm{~g} \mathrm{C} \mathrm{kg}^{-1}$ soil, respectively. The proportion of $<53 \mu \mathrm{m}$ organic carbon in SOC did not show significant differences among the 10 climax communities, with a mean value of $19.44 \%$.

Table 3. Contents change of soil total organic carbon and fraction carbon.

\begin{tabular}{|c|c|c|c|c|c|c|}
\hline Area & Succession Stage & $\begin{array}{c}>250 \mu \mathrm{m} \text { Fraction } \mathrm{C} \\
\text { Content } \\
\left(\mathrm{g} \mathrm{C} \mathrm{kg}^{-1} \text { Soil }\right)\end{array}$ & $\begin{array}{c}\text { 53-250 } \mu \mathrm{m} \text { Fraction } \\
\mathrm{C} \text { Content } \\
\left(\mathrm{g} \mathrm{C} \mathrm{kg}^{-1} \text { Soil }\right)\end{array}$ & $\begin{array}{c}<53 \mu \mathrm{m} \text { Fraction C } \\
\text { Content } \\
\left(\mathrm{g} \mathrm{C} \mathrm{kg} \mathrm{g}^{-1} \text { Soil }\right)\end{array}$ & $\begin{array}{l}\text { Soil Organic C } \\
\text { Content } \\
\text { (g C kg } \text { }^{-1} \text { Soil) }\end{array}$ & $\begin{array}{c}\text { Proportion of }<53 \mu \mathrm{m} \mathrm{C} \\
\text { to Total Organic C } \\
\text { (g Fraction } 100 \mathrm{~g}^{-1} \text { Soil) }\end{array}$ \\
\hline \multirow{3}{*}{ Maolan } & Herb stage & $17.33 \pm 0.62 \mathrm{~d}$ & $7.50 \pm 0.46 \mathrm{~d}$ & $3.51 \pm 0.38 \mathrm{~d}$ & $28.34 \pm 2.80 \mathrm{~d}$ & $12.39 \pm 0.55 c$ \\
\hline & Shrub stage & $31.91 \pm 1.50 c$ & $22.77 \pm 1.19 c$ & $10.62 \pm 0.68 c$ & $65.30 \pm 4.36 c$ & $16.26 \pm 0.43 b$ \\
\hline & Arbor stage & $39.49 \pm 2.46 b$ & $30.35 \pm 2.55 b$ & $15.38 \pm 1.29 b$ & $85.22 \pm 3.69 b$ & $18.05 \pm 0.62 \mathrm{a}$ \\
\hline & Climax stage & $43.77 \pm 2.35 \mathrm{aB}$ & $33.19 \pm 2.33 \mathrm{aB}$ & $17.17 \pm 0.73 \mathrm{aB}$ & $94.13 \pm 3.51 \mathrm{aB}$ & $18.24 \pm 1.03 \mathrm{aA}$ \\
\hline & $\overline{\text { Herb }} \overline{\text { stage }}-$ & $\overline{17 . \overline{3} 2}+\overline{1} 1 . \overline{12} \bar{c}$ & $-3 . \overline{31} \pm \overline{0} . \overline{29} \overline{\mathrm{d}}$ & $\overline{1} .8 \overline{9} \overline{ \pm 0.19 \mathrm{c}}$ & $\overline{2} 2 . \overline{5} 2 \pm \overline{0} . \overline{4} \mathrm{~d}-$ & $-8 . \overline{3} \overline{ \pm} \overline{0} . \overline{1} \mathrm{~b}^{-}$ \\
\hline \multirow{2}{*}{ Yuntai Mountain } & Shrub stage & $20.70 \pm 1.23 c$ & $16.70 \pm 1.61 c$ & $4.06 \pm 0.21 c$ & $41.46 \pm 1.75 c$ & $9.79 \pm 0.32 b$ \\
\hline & Arbor stage & $27.58 \pm 2.67 \mathrm{~b}$ & $20.58 \pm 3.31 b$ & $10.68 \pm 0.98 b$ & $58.84 \pm 4.61 \mathrm{~b}$ & $18.15 \pm 0.65 a$ \\
\hline & Climax stage & $38.06 \pm 1.48 \mathrm{aB}$ & $27.97 \pm 1.70 \mathrm{aBC}$ & $16.10 \pm 2.48 \mathrm{aB}$ & $82.13 \pm 2.08 \mathrm{aC}$ & $19.60 \pm 0.24 \mathrm{aA}$ \\
\hline & $-\overline{\text { Herb }} \overline{\text { stage }}-$ & $\overline{14.69} \pm \overline{1} . \overline{10} \mathrm{c}^{-}$ & $2.20 \pm 0 . \overline{2} 1 \overline{\mathrm{d}}$ & $-\overline{1} .4 \overline{6} \overline{ \pm} 0 . \overline{1} \overline{\mathrm{c}}$ & $-\overline{18} . \overline{3} 5 \pm \overline{0} . \overline{97} \mathrm{~d}^{-}$ & $7 . \overline{9} 6 \pm \overline{0} . \overline{13} c^{-}-$ \\
\hline \multirow{2}{*}{ Dashahe } & Shrub stage & $17.46 \pm 0.82 c$ & $9.58 \pm 0.96 c$ & $2.19 \pm 0.24 c$ & $29.23 \pm 0.84 c$ & $7.49 \pm 0.28 c$ \\
\hline & Arbor stage & $28.93 \pm 2.63 b$ & $15.25 \pm 1.74 b$ & $5.75 \pm 0.52 b$ & $49.93 \pm 3.21 b$ & $11.52 \pm 0.44 b$ \\
\hline \multirow{3}{*}{$---\overline{\text { Nayong }}--$} & Climax stage & $39.01 \pm 2.01 \mathrm{aB}$ & $24.22 \pm 2.13 \mathrm{aC}$ & $15.52 \pm 0.81 \mathrm{aB}$ & $78.75 \pm 2.45 \mathrm{aCD}$ & $19.71 \pm 0.36 \mathrm{aA}$ \\
\hline & - Climax stage- & $\overline{6} 9 . \overline{2} 1 \pm \overline{3} . \overline{42} \overline{\mathrm{A}}$ & $\overline{54.3 \overline{4}} \pm \overline{4} . \overline{5} 1 \overline{\mathrm{A}}$ & $2 \overline{3} .5 \overline{6} \pm 3 . \overline{87 \mathrm{~A}}$ & $-\overline{4} 7 \overline{1} \overline{1} 1 \pm \overline{6} . \overline{55} \overline{\mathrm{A}}$ & $\overline{1} 8 . \overline{4} 2 \overline{0} \overline{0.52} \overline{\mathrm{A}}$ \\
\hline & Climax stage & $41.69 \pm 4.74 \mathrm{~B}$ & $24.65 \pm 2.58 C$ & $15.44 \pm 1.43 \mathrm{~B}$ & $81.78 \pm 8.89 C$ & $18.88 \pm 0.34 \mathrm{~A}$ \\
\hline \multirow{2}{*}{$\begin{array}{l}\text { Kuankuoshui } \\
\text { Huoyan } \\
\text { mountain }\end{array}$} & Climax stage & $29.06 \pm 1.99 \mathrm{C}$ & $18.99 \pm 1.23 \mathrm{D}$ & $11.45 \pm 0.28 \mathrm{C}$ & $59.50 \pm 4.79 \mathrm{DE}$ & $19.24 \pm 1.17 \mathrm{~A}$ \\
\hline & Climax stage & $28.22 \pm 1.53 \mathrm{C}$ & $12.18 \pm 0.93 \mathrm{E}$ & $9.03 \pm 1.73 \mathrm{D}$ & $49.43 \pm 0.63 \mathrm{E}$ & $21.09 \pm 0.70 \mathrm{~A}$ \\
\hline $\begin{array}{l}\text { Huanggu } \\
\text { mountain }\end{array}$ & Climax stage & $39.65 \pm 1.56 \mathrm{~B}$ & $20.52 \pm 0.76 \mathrm{D}$ & $15.62 \pm 1.77 \mathrm{~B}$ & $75.79 \pm 1.39 \mathrm{CD}$ & $20.61 \pm 2.26 \mathrm{~A}$ \\
\hline Zijiang rift valley & tage & $17.95 \pm$ & $15.80 \pm 0.99 \mathrm{DE}$ & $8.30=$ & 42.0 & 19.74 \\
\hline Bijia mountain & Climax stage & $32.20 \pm 2.15 \mathrm{C}$ & $20.95 \pm 1.64 \mathrm{D}$ & $12.26 \pm 1.49 \mathrm{C}$ & $65.41 \pm 6.03 \mathrm{D}$ & $18.82 \pm 0.25 \mathrm{~A}$ \\
\hline
\end{tabular}

Note: Different lowercase letters indicate a significant difference $(p<0.05)$ among different succession stages, different capital letters indicate a significant difference $(p<0.05)$ among different climax stages for each fraction, $\mathrm{C}$ content and proportion are reported as mean $\pm \mathrm{SE}$. 


\subsection{CSD Characteristics}

The maximum saturation capacity of SOC in karst forests was modelled as $y=0.66 x$ $\left(R^{2}=0.78\right)$ (Figure 2), and the maximum saturation values of SOC in Maolan, Yuntai Mountain, and Dashahe were $20.70 \%, 18.88 \%$, and $14.55 \%$, respectively, according to the model. The CSD in karst forests showed significant differences at different successional stages (Figure 3). The CSD in the herb stage was the highest in Maolan, Yuntai Mountain, and Dashahe at $83.04 \%, 89.99 \%$, and $89.97 \%$, respectively, followed by the shrub stage at $48.69 \%, 78.50 \%$, and $84.95 \%$, and the lowest in the arbor stage at $25.69 \%, 43.44 \%$, and $60.49 \%$. The CSD values in the herb stage were 1.71, 1.15, and 1.06 and 3.23, 2.07, and 1.49 times higher than those in the shrub and arbor stages, respectively. The CSD in karst forests showed an overall increasing trend from south to north.

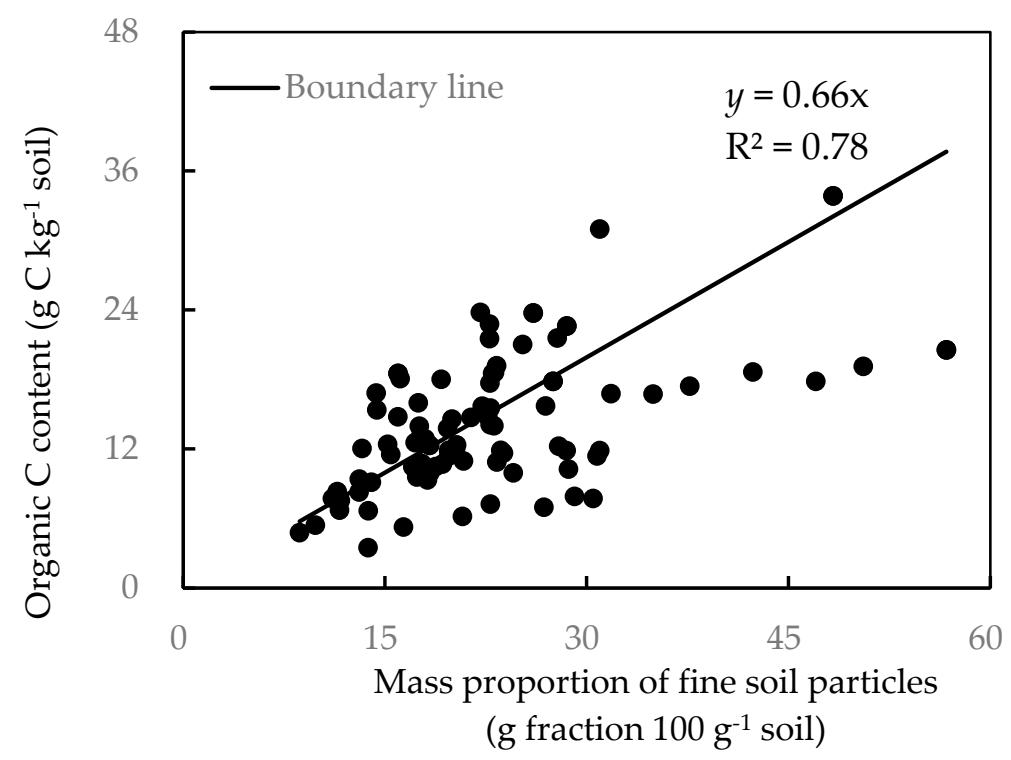

Figure 2. Boundary line analysis of organic $C$ content $\left(\mathrm{g} \mathrm{C} \mathrm{kg}^{-1}\right.$ soil) of $<53 \mu \mathrm{m}$ particles with their mass proportions ( $\mathrm{g}$ fraction $100 \mathrm{~g}^{-1}$ soil) in all bulk soils.

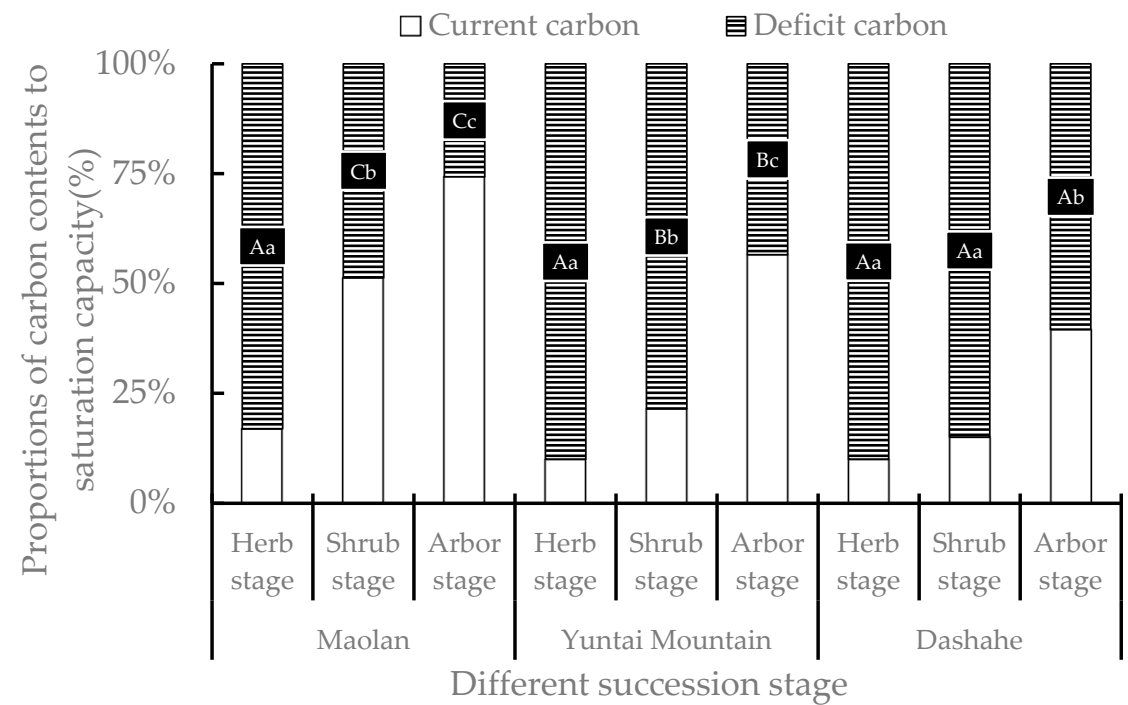

Figure 3. Saturated deficit of soil organic carbon at different succession stages in different regions (Note: Different lowercase letters indicate a significant difference $(p<0.05)$ among different succession stages, different capital letters indicate a significant difference $(p<0.05)$ among different regions). 


\subsection{Analysis of the Main Drivers of CSD}

The main drivers of CSD differed significantly between karst forests (Table 4). In Maolan, the multiple stepwise regression model showed a significant relationship between CSD and litter carbon input, total nitrogen, total phosphorus, and total SOC, with an $\mathrm{R}^{2}$ of 0.96 and a significant model fit $(p<0.01)$. In Yuntai Mountain, the regression model showed that the CSD was linearly related to the amount of litter carbon input $\left(\mathbf{R}^{2}=0.90 ; p<0.05\right)$. In Dashahe, the stepwise regression model showed a significant relationship between CSD and litter carbon input and neutral phosphatase (corrected $\mathrm{R}^{2}=0.91 ; p<0.05$ ). All three karst forests showed a significant regression between CSD and litter carbon input, and the larger the coefficient, the smaller the contribution to CSD. The trend of CSD was Maolan > Yuntai Mountain > Dashahe when equal amounts of litter were considered.

Table 4. Regression model between soil organic carbon saturation deficit (CSD) and major driving factors.

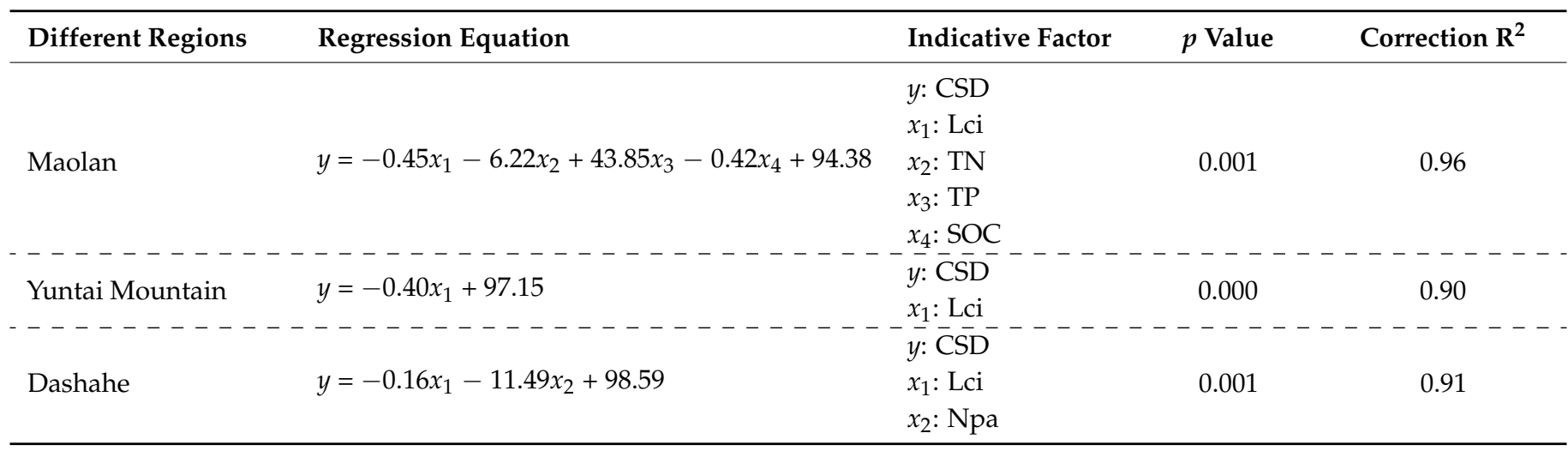

Note: CSD is soil organic carbon saturation deficit, Lci is litter carbon input, TN is total nitrogen, TP is total phosphorus, $\mathrm{SOC}$ is soil total organic carbon, $\mathrm{Npa}$ is neutral phosphatase.

\section{Discussion}

\subsection{Characteristics of the Changes in SOC Content}

The results of this study demonstrated that the carbon fraction and SOC content increased as succession progressed, consistent with the results of other studies [32,33] and indicating that the climax stage is the main carbon sink of karst forest ecosystems and that it has a high carbon sequestration capacity. The main reason for this is that the litter carbon input increased significantly as succession progressed (Table 2), with $12.27 \mathrm{~g} / \mathrm{m}^{2}$, $23.33 \mathrm{~g} / \mathrm{m}^{2}$, and $21.27 \mathrm{~g} / \mathrm{m}^{2}$ in the herb stage of Maolan, Yuntai Mountain, and Dashahe, respectively, reaching $141.03 \mathrm{~g} / \mathrm{m}^{2}, 181.11 \mathrm{~g} / \mathrm{m}^{2}$, and $204.71 \mathrm{~g} / \mathrm{m}^{2}$ in the climax stage, values that were 11.49 and 7.76 times higher than those in the herb stage. The amount of litter carbon input is the main source of forest soil carbon and directly affects the SOC balance $[15,34,35]$. Meanwhile, a large number of studies have found that increased carbon input may have a negative excitation effect on soil original organic carbon and inhibit its native soil organic carbon $[19,36,37]$. The root system is also a source of soil carbon input, and the dominant tree species in both the arbor and climax stages were mixed with evergreen, deciduous broad-leaved trees (Table 1) with well-developed root systems and greater carbon input to the soil. In contrast, the dominant species in the herb and shrub stages were herbs or shrubs (Table 1) with less-developed root systems and less carbon input to the soil. The soil microorganisms play a crucial role in the SOC sequestration process, regulating the SOC balance in both directions [38,39]. The successional sequence from the herb stage to the climax stage can improve the soil agglomeration structure by increasing microbial biomass, especially fungal mycelia; this increases soil organic cementation that in turn increases the physical conservation of SOC [36,40]. The structure and activity of soil microbial communities differ at various successional stages, and fungal cell residues, especially cell wall components, are more difficult to decompose than bacteria. Thus it 
is possible that a higher proportion of fungi in the climax stage increases the stability of SOC $[6,41]$.

Many studies have suggested that climatic factors, especially temperature and precipitation, are the most important determinants of SOC distribution at large scales $[18,37,42]$. The positive relationship between temperature and precipitation and SOC in forests has been highlighted in global and more regional studies [43,44]. In our study, there were significant differences in SOC content among the karst forests with different temperatures and precipitation. Maolan had the highest temperature and precipitation $\left(19.75^{\circ} \mathrm{C}\right.$, $1590.70 \mathrm{~mm}$ ) (Table 2), and SOC content was also the highest. On the contrary, Dashahe had the lowest temperature $\left(16.81^{\circ} \mathrm{C}\right)$ and average precipitation $(1372.20 \mathrm{~mm})$ (Table 2), and SOC content was the lowest. This is consistent with the results from studies on a global scale and numerous regional scales $[33,45]$. Temperature and precipitation increase could significantly enhance the bio-productivity and accelerate the decomposition rate of litter, thus increasing the input of SOC. When the amount of exogenous carbon input is greater than the amount of SOC mineralization, it is beneficial to the accumulation of SOC $[45,46]$.

\subsection{Characteristics of the Changes in CSD}

CSD is an indicator of the level of future carbon sequestration potential of SOC or the amount of space available for sequestration [47]. The greater the CSD, the greater the potential for future sequestration of SOC. In this study, CSD was highest in the herb stages of Maolan, Yuntai Mountain, and Dashahe at $83.04 \%, 89.99 \%$, and $89.97 \%$, respectively, followed by $48.69 \%, 78.50 \%$, and $84.95 \%$ in the shrub stage and being lowest in the arbor stage at $25.69 \%, 43.44 \%$, and $60.49 \%$ (Figure 3), indicating that as succession progressed, the CSD decreased. The future carbon sequestration potential gradually decreased, i.e., the herb stage had the most space for carbon sequestration, followed by the shrub and arbor stages. In the three karst forests, the CSD was not significantly different between the herb stages of Maolan, Yuntai Mountain, and Dashahe, while there was a trend of Dashahe > Yuntai Mountain > Maolan at the shrub and arbor stages. On the whole, the CSD showed a gradual increase from south to north, indicating that the future carbon sequestration potential of Dashahe is the largest, followed by Yuntai Mountain and Maolan. On a large spatial scale, $\mathrm{Xu}$ et al. [48] found that the CSD in the surface layer of the Daxinganling Forest was $2.20 \%$ and $78.80 \%$ in the deep layer, indicating that the deep layer had a greater potential for carbon sequestration. Zhang [49] found that the CSD in a protected forest in a desert zone was $27.58 \%$. CSD varies from region to region and is related to the maximum saturation of SOC and the organic carbon content of existing soil mineral particles [9]. In this study, the CSD was related to the organic carbon content of the $<53 \mu \mathrm{m}$ fraction, and the closer the organic carbon content of the $<53 \mu \mathrm{m}$ fraction to the climax stage, the lower the CSD, and the opposite is true. In this study, as succession proceeded, the organic carbon content of the $<53 \mu \mathrm{m}$ fraction increased and was greatest in the karst forest at Maolan, lower at Yuntai Mountain, and least at Dashahe (Table 3). Therefore, regarding the future of karst forests, development should be conducted from north to south as far as possible, and priority should be given to grassland and shrub stages in order to achieve the maximum relative carbon sequestration capacity.

\subsection{Analysis of the Main Drivers of the CSD}

CSD is influenced by multiple interacting factors and involves complex processes [50-53]. In this study, the main drivers of CSD in different karst forests were litter carbon input, total nitrogen, total phosphorus, and total SOC in Maolan, litter carbon input in Yuntai Mountain, and litter carbon input and neutral phosphatase in Dashahe. The results showed that the ecosystem structure of Maolan was the most complex among the different karst forests, and there was an overlap of environmental factors. Therefore, the CSD was influenced by multiple factors. Yuntai Mountain and Dashahe have relatively simple ecosystem structures, so there are few controlling factors. Litter carbon input is the main driving factor of CSD in karst forests, reflecting the important role of litter in maintaining soil carbon 
balance in karst forests. As the main source of the soil carbon pool, litter decomposition and accumulation will affect the dynamic balance of SOC [54,55]. The amount of carbon input to litter is controlled by litter quality and external environmental conditions, and these two factors can be adjusted to control the litter carbon input [56,57]. Litter regulates CSD by affecting multiple factors such as soil microbial community structure and native soil organic carbon excitation. Phosphatase is one of the most active enzymes in soil. It is an important indicator enzyme for the characterization of soil biological activity, and it plays an important role in soil phosphorus cycling [58]. In this study, neutral phosphatase might affect carbon sequestration by changing soil fertility or might affect the amount of litter carbon input by changing the phosphorus absorption capacity of plants, thus affecting CSD. The results of this study were generally consistent with those of other researchers. Tian et al. [59] found that the factors affecting SOC stability at different elevation gradients were temperature, litter, and soil physicochemical properties. Liu et al. [60] found that the main controlling factors of SOC in Moso bamboo forests were soil porosity, capacitance, and soil enzyme activity. Guan et al. [45] found that the main influencing factors of SOC in northwestern forest ecosystems were standing age, temperature, humidity, elevation, and litter. In conclusion, although the main drivers of CSD in karst forests vary, the core driver is the amount of litter carbon input; therefore, this factor could be adjusted to regulate CSD in the future.

\section{Conclusions}

By constructing the maximum saturated capacity model of SOC in karst forests, we estimated the saturated deficit of SOC in different regions and succession stages and analyzed its main driving factors. The soil carbon fraction and SOC content in karst forests followed the pattern climax stage $>$ arbor stage $>$ shrub stage $>$ herb stage, and the SOC content in different karst forests was Maolan > Yuntai Mountain > Dashahe. The CSD in the herb stages of Maolan, Yuntai Mountain, and Dashahe were the highest, and the future carbon sequestration potential of the herb stage was increased from south to north, with greater potential for exploitation. The core driver of CSD in forest ecosystems of the karst forests is the amount of litter carbon input, which can be adjusted to control CSD in karst forests.

Author Contributions: Conceptualization, L.Z. and L.Y.; methodology, J.C. and Y.W.; formal analysis, L.Z.; investigation, F.L. and L.F.; resources, L.Y.; writing — original draft preparation, L.Z.; writingreview and editing, L.Z.; supervision, L.Y.; funding acquisition, L.Y. All authors have read and agreed to the published version of the manuscript.

Funding: This research was funded by the Project of National Key Research and Development Program of China (grant number 2016YFC0502604); the Application Foundation Major Project of Guizhou Province of China (Qian Ke He JZ [2014] 2002); the Construction Program of Biology Firstclass Discipline in Guizhou of China (GNYL [2017]009); and the Project of Promoted Innovation of Colleges and Universities of Guizhou Province of China (Qian Jiao He Collaborative Innovation [2014]01).

Institutional Review Board Statement: No animal interventions were used in this research.

Data Availability Statement: All data are available on request.

Acknowledgments: We sincerely thank Meng $\mathrm{Xu}$ and his team for their help and support during the manuscript writing process.

Conflicts of Interest: The authors declare no conflict of interest.

\section{Abbreviations}

SOC: Soil organic carbon; CSD: Carbon saturation deficit. 


\section{References}

1. Panja, P. Deforestation, Carbon dioxide increase in the atmosphere and global warming: A modelling study. Int. J. Model. Simul. 2019, 3, 209-219. [CrossRef]

2. Samaneh, T.; Shamsollah, A.; Mojtaba, Z. Digital mapping of soil organic carbon using ensemble learning model in Mollisols of Hyrcanian forests, northern Iran. Geoderma Reg. 2020, 20, e00256. [CrossRef]

3. Mojtaba, Z.; Garosi, Y.; Reza, O.H.; Ayoubi, S.; Taghizadeh, M.R.; Scholten, T.; Xu, M. Improving the spatial prediction of soil organic carbon using environmental covariates selection: A comparison of a group of environmental covariates. Catena 2021, 208, 105727. [CrossRef]

4. Zhu, J.X.; Hu, H.F.; Tao, S.L.; Chi, X.L.; Jiang, L.; Ji, C.J.; Zhu, J.L.; Tang, Z.Y.; Pan, Y.D.; Richard, A.B. Carbon stocks and changes of dead organic matter in China's forests. Nat. Commun. 2017, 1, 151. [CrossRef] [PubMed]

5. Tao, Y.J.; Duan, M.S.; Deng, Z. Using an extended theory of planned behaviour to explain willingness towards voluntary carbon offsetting among Chinese consumers. Ecol. Econ. 2021, 2, 174-185. [CrossRef]

6. $\quad$ Sayer, E.J.; Baxendale, C.; Birkett, A.J.; Bréchet, L.M.; Castro, B.; Deirdre, K.B.; Luis, L.S.; Chadtip, R. Altered litter inputs modify carbon and nitrogen storage in soil organic matter in a lowland tropical forest. Biogeochemistry 2020, 1, 23-34. [CrossRef]

7. Zhuang, Y.; Zhu, J.; Shi, L.; Fu, Q.L.; Hu, H.Q.; Huang, Q.Y. Influence mechanisms of iron, aluminum and manganese oxides on the mineralization of organic matter in paddy soil. J. Environ. Manag. 2021, 301, 10-20. [CrossRef]

8. Almeida, F.J.; Souza, I.F.; Hurtarte, C.C.; Teixeira, P.P.C.; Inagaki, T.M.; Silva, I.R.; Mueller, C.W. Forest litter constraints on the pathways controlling soil organic matter formation. Soil Biol. Biochem. 2021, 4, 142-153. [CrossRef]

9. West, T.O.; Six, J. Considering the influence of sequestration duration and carbon saturation on estimates of soil carbon capacity. Clim. Chang. 2007, 80, 25-41. [CrossRef]

10. Stewart, C.E.; Plante, A.F.; Paustian, K.P.; Conant, R.T.; Six, J. Soil carbon saturation: Linking concept and measurable carbon pools. Soil Sci. Soc. Am. J. 2008, 72, 379-392. [CrossRef]

11. Feng, W.T.; Plante, A.F.; Six, J. Improving estimates of maximal organic carbon stabilization by fine soil particles. Biogeochemistry 2013, 112, 81-93. [CrossRef]

12. Liu, G.H.; Fu, B.J.; Fang, J.Y. Carbon dynamics of Chinese forests and its contribution to global carbon balance. Acta Ecol. Sin. 2000, 5, 733-740.

13. Sun, K.; Li, J.Q.; Yang, G.L.; Zhuo, M.; Hu, J. Effect of alterations in forest litter inputs on soil C and N storage distribution in pinus yunnanensis forest in central Yunnan Plateau. Acta Ecol. Sin. 2021, 41, 3100-3110. [CrossRef]

14. Zhou, Y.R.; Yu, Z.L.; Zhao, S.D. Carbon storage and budget of major Chinese forest types. Chin. J. Plant Ecol. 2000, $24,518-522$.

15. Huang, Z.S.; Yu, L.F.; Fu, Y.H.; Yang, R. Characteristics of carbon sequestration during natural restoration of Maolan karst forest ecosystems. Chin. J. Plant Ecol. 2015, 39, 554-564.

16. Zhang, L.; Zhang, D.L.; Mao, Z.J. Characteristic mineralization of soil organic carbon in different successional series of broadleaved Korean pine forests in the temperate zone in China. Acta Ecol. Sin. 2017, 37, 6370-6378. [CrossRef]

17. Lai, R.; Follett, R.F.; Stewart, B.A.; Kimble, J.M. Soil carbon sequestration to mitigate climate change and advance food security. Soil Sci. 2007, 172, 943-956. [CrossRef]

18. Di, J.Y.; Xu, M.G.; Zhang, W.J.; Tong, X.G.; He, X.H.; Gao, H.J.; Liu, H.; Wang, B.R. Combinations of soil properties, carbon inputs and climate control the saturation deficit dynamics of stable soil carbon over 17-year fertilization. Sci. Rep. 2018, 8, 12653. [CrossRef]

19. Yu, L.F. Research on Ecological Process of Natural Restoration of Degraded Karst Forest. Ph.D. Thesis, Nanjing Forestry University, Nanjing, China, 1998.

20. Hamer, U.; Marschner, B. Priming effects in different soil types induced by fructose, alanine, oxalic acid and catechol additions Soil Biol. Biochem. 2005, 37, 445-454. [CrossRef]

21. Rietz, D.N.; Haynes, R.J. Effects of irrigation-induced salinity and sodicity on soil microbial activity. Soil Biol. Biochem. 2003, 35, 845-854. [CrossRef]

22. Hu, N.; Li, H.; Tang, Z.; Li, Z.F.; Li, G.C.; Jiang, Y.; Hu, X.M.; Lou, Y.L. Community size, activity and C:N stoichiometry of soil microorganisms following reforestation in a Karst region. Eur. J. Soil Biol. 2016, 73, 77-83. [CrossRef]

23. Liu, S.J.; Zhang, W.; Wang, K.L.; Pan, F.J.; Yang, S.; Shu, S.Y. Factors controlling accumulation of soil organic carbon along vegetation succession in a typical karst region in Southwest China. Sci. Total Environ. 2015, 521, 52-58. [CrossRef]

24. Xiao, K.C.; He, T.G.; Chen, H.; Peng, W.X.; Song, T.Q.; Wang, K.L.; Li, D.J. Impacts of vegetation restoration strategies on soil organic carbon and nitrogen dynamics in a karst area, southwest China. Ecol. Eng. 2017, 101, 247-254. [CrossRef]

25. Huang, C.J. Main vegetation types and distribution characteristics in Yuntai Mountain, Shibing, Guizhou province of China. Guizhou For. Sci. Technol. 1995, 23, 26-30.

26. Luo, X.J.; Li, Q.M.; Feng, Y.C.; Wang, L.H.; Jiang, Y.L. Biodiversity and floristic characteristics of orchids in Dashahe Nature Reserve, Daozhen, Guizhou province of China. Guizhou For. Sci. Technol. 2013, 41, 19-23.

27. Dong, M. Plant clonal growth in heterogeneous habitats: Risk-spreading. Chin. J. Plant Ecol. 1996, 6, 543-548.

28. Six, J.; Conant, R.T.; Paul, E.A.; Paustian, K. Stabilization mechanisms of soil organic matter: Implications for C-saturation of soils. Plant Soil 2002, 241, 155-176. [CrossRef]

29. Bao, S.D. Soil Agrochemical Analysis, 3rd ed.; China Agriculture Press: Nanjing, China, 2001; pp. 3-109. 
30. Guan, S.Y. Soil Enzymes and Research Methods; Agricultural Press: Beijing, China, 1986; pp. $294-297$.

31. Zhu, X.N. R Language; Renmin University of Chinese Press: Beijing, China, 2018; pp. 1-352.

32. Wang, C.Q.; Xue, L.; Jiao, R.Z. Soil organic carbon fractions, C-cycling associated hydrolytic enzymes, and microbial carbon metabolism vary with stand age in Cunninghamia lanceolate (Lamb.) Hook plantations. For. Ecol. Manag. 2021, $48,482-496$. [CrossRef]

33. Wu, Y.N.; Yu, L.F.; Zhang, L.M.; Liu, N.; Yan, L.B. Characteristics and influencing factors of soil carbon pool during vegetation restoration in Karst Plateau. Ecol. Environ. Sci. 2020, 29, 1935-1942. [CrossRef]

34. Ge, T.D.; Yuan, H.Z.; Zhu, H.H.; Wu, X.H.; Nie, S.A.; Liu, C.; Tong, C.L.; Wu, J.S.; Brookes, P. Biological carbon assimilation and dynamics in a flooded rice-soil system. Soil Biol. Biochem. 2012, 48, 39-49. [CrossRef]

35. Raich, J.W.; Schlesinger, W.H. The global carbon dioxide flux in soil respiration and its relationship to vegetation and climate. Tellus 1992, 44B, 81-99. [CrossRef]

36. Elipe, B.; Carlos, G.; Noah, F.; David, J.E.; Matthew, A.B.; Sebastián, A.; Fernando, D.A.; Asmeret, A.B.; Nick, A.C.; Antonio, G.; et al Global ecological predictors of the soil priming effect. Nat. Commun. 2019, 10, 3481.

37. Zhang, L.M.; Xu, M.G.; Lou, Y.L.; Wang, X.L.; Qing, S.; Jiang, T.M.; Li, Z.F. Changes in Yellow paddy soil organic carbon fractions under long-term fertilization. Sci. Agric. Sin. 2014, 47, 3817-3825. [CrossRef]

38. Chen, Z.M.; Wang, H.Y.; Liu, X.W.; Zhao, X.L.; Lu, D.J.; Zhou, J.M.; Li, C.Z. Changes in soil microbial community and organic carbon fractions under short-term straw return in a rice-wheat cropping system. Soil Tillage Res. 2017, 16, 121-127. [CrossRef]

39. Lan, L.Y.; Yang, W.Q.; Wu, F.Z.; Liu, Y.W.; Guo, C.H.; Zhan, Y.; Tan, B. Effects of soil fauna on microbial community during litter decomposition of populus simonii and fargesia spathacea in the subalpine forest of western Sichuan, China. Chin. J. Appl. Ecol. 2019, 30, 2983-2991. [CrossRef]

40. Fontaine, S.; Mariotti, A.; Abbadie, L. The priming effect of organic matter: A question of microbial competition. Soil Biol. Biochem. 2003, 35, 837-843. [CrossRef]

41. Elliott, E.T.; Paustian, K.; Frey, S.D. Modeling the Measurable or Measuring the Modelable: A Hierarchical Approach to Isolating Meaningful Soil Organic Matter Fractionations. In Evaluation of Soil Organic Matter Models; Nato Asiseries; Springer: Berlin/Heidelberg, Germany, 1996; Volume 2, pp. 161-179.

42. Soh, S.; Makoto, S.; Antoine, D.M.Z.; Haruo, T.; Takashi, K.; Shinya, F. Forest understories controlled the soil organic carbon stock during the fallow period in African tropical forest: A ${ }^{13}$ C analysis. Sci. Rep. 2019, 9, 9835-9843. [CrossRef]

43. Callesen, I.; Liski, J.; Raulund-Rasmussen, K.; Olsson, M.T.; Tau-Strand, L.V.; Westman, C.J. Soil carbon stores in Nordic well-drained forest soils-Relationships with climate and texture class. Glob. Chang. Biol. 2003, 9, 358-370. [CrossRef]

44. Wiesmeier, M.; Jörg, P.; Frauke, B.; Peter, S.; Uwe, G.; Edzard, H.; Arthur, R.; Bernd, S.; Margit, V.L.; Ingrid, K.K. Storage and drivers of organic carbon in forest soils of southeast Germany (Bavaria)-Implications for carbon sequestration. For. Ecol. Manag. 2013, 295, 162-172. [CrossRef]

45. Guan, J.H.; Deng, L.; Zhang, J.G.; He, Q.Y.; Shi, W.Y.; Li, G.Q.; Du, S. Soil organic carbon density and its driving factors in forest ecosystems across a northwestern province in China. Geoderma 2019, 352, 1-12. [CrossRef]

46. Schuman, G.E.; Janzen, H.H.; Herrick, J.E. Soil carbon dynamics and potential carbon sequestration by rangelands. Environ. Pollut. 2002, 116, 391-396. [CrossRef]

47. Merabtene, M.D.; Faraoun, F.; Mlih, R.; Riad, D.; Ali, L.; Roland, B. Forest Soil Organic Carbon Stocks of Tessala Mount in North-West Algeria-Preliminary Estimates. Front. Environ. Sci. 2021, 120, 125-138. [CrossRef]

48. Xu, J.H.; Gao, L.; Sun, Y.; Cui, X.Y. Distribution of mineral-bonded organic carbon and black carbon in forest soils of great Xing'an mountains, China and carbon sequestration potential of the soils. Acta Pedol. Sin. 2018, 55, 236-246. [CrossRef]

49. Zhang, Q. Soil Carbon Distribution Characteristics and Carbon Sequestration Potential Estimation of Highway Shelterbelt in Taklimakan Desert; Northwest Agricultural \& Forest University: Shanxi, China, 2019.

50. Bertrand, I.; Delfosse, O.; Mary, B. Carbon and nitrogen mineralization in acidic, limed and calcareous agricultural soils: Apparent and actual effects. Soil Biol. Biochem. 2007, 39, 276-288. [CrossRef]

51. Oren, A.; Steinberger, Y. Coping with artifacts induced by $\mathrm{CaCO}_{3}-\mathrm{CO}_{2}-\mathrm{H}_{2} \mathrm{O}$ equilibria in substrate utilization profiling of calcareous soils. Soil Biol. Biochem. 2008, 40, 2569-2577. [CrossRef]

52. Di, J.Y. Characteristics and Driving Factors of Mineral Combined Organic Carbon Saturation Deficit in Typical Farmland Soils under Long-Term Fertilization; Chinese Academy of Agricultural Sciences: Beijing, China, 2017.

53. Sun, Z.X.; Bai, H.Q.; Ye, H.C.; Zhuo, Z.Q.; Huang, W.J. Three-dimensional modelling of soil organic carbon density and carbon sequestration potential estimation in a dryland farming region of China. J. Geogr. Sci. 2021, 31, 1453-1468. [CrossRef]

54. Dray, R.; Gorham, E. Litter production in forest of the world. Adv. Res. 1964, 2, 101-157.

55. Wang, X.P.; Yang, X.; Yang, N.; Xin, X.J.; Qu, Y.B.; Zhao, L.X.; Gao, Y.B. Effects of litter diversity and composition on litter decomposition characteristics and soil microbial community. Acta Ecol. Sin. 2019, 39, 1-9. [CrossRef]

56. Hartley, I.P.; Gatnett, M.H.; Hopkins, D.W.; Fletcher, B.J.; Sloan, V.L.; Phoenix, G.K.; Wookey, P.A. A potential loss of carbon associated with greater plant growth in the European Arctic. Nat. Clim. Chang. 2012, 12, 875-879. [CrossRef]

57. Qin, Y.B.; Xin, Z.B.; Wang, D.M.; Xiao, Y.L. Soil organic carbon storage and its influencing factors in the riparian woodlands of a Chinese karst area. Catena 2017, 15, 21-29. [CrossRef]

58. Chen, J.; Sinsabaugh, R.L. Linking microbial functional gene abundance and soil extracellular enzyme activity: Implications for soil carbon dynamics. Glob. Chang. Biol. 2021, 27, 122-135. [CrossRef] [PubMed] 
59. Tian, Q.X.; He, H.B.; Cheng, W.X.; Zhen, B.; Wang, Y.; Zhang, X.D. Factors controlling soil organic carbon stability along a temperate forest altitudinal gradient. Sci. Rep. 2016, 6, 242-258. [CrossRef] [PubMed]

60. Liu, X.X.; Luan, Y.N.; Dai, W.; Wang, B.; Dai, A. Factors affecting soil organic carbon in a Phyllostachys edulis forest. J. For. Res. 2019, 30, 1487-1494. [CrossRef] 